\title{
Ferrocyanide Safety Program: Moisture Migration Test in Ferrocyanide Simulant
}

\author{
M. D. Crippen
}

Date Published

August 1994

Prepared for the U.S. Department of Energy Office of Environmental Restoration and Waste Management

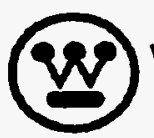




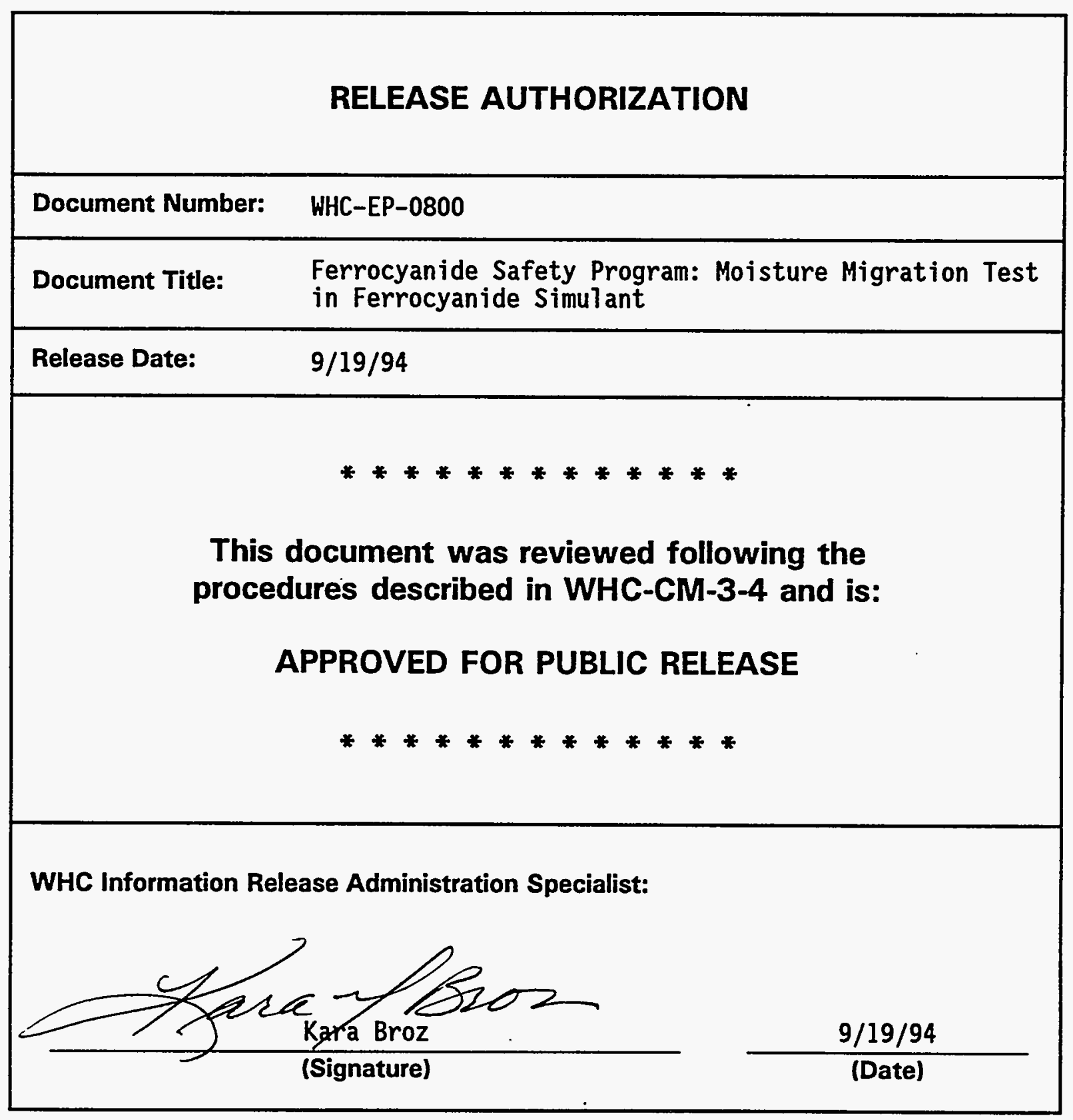

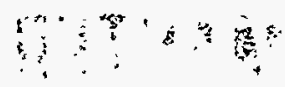




\section{DISCLAIMER}

This report was prepared as an account of work sponsored by an agency of the United States Government. Neither the United States Government nor any agency thereof, nor any of their employees, make any warranty, express or implied, or assumes any legal liability or responsibility for the accuracy, completeness, or usefulness of any information, apparatus, product, or process disclosed, or represents that its use would not infringe privately owned rights. Reference herein to any specific commercial product, process, or service by trade name, trademark, manufacturer, or otherwise does not necessarily constitute or imply its endorsement, recommendation, or favoring by the United States Government or any agency thereof. The views and opinions of authors expressed herein do not necessarily state or reflect those of the United States Government or any agency thereof. 


\section{DISCLAIMER}

Portions of this document may be illegible in electronic image products. Images are produced from the best available original document. 


\title{
WHC-EP-0800
}

\begin{abstract}
Tests were conducted in a 400-L volume of ferrocyanide sludge simulant to determine thermal characteristics around heated zones. At low heat loads, surface vapor losses were much lower than return rates, resulting in no net change in water content. Under boiling conditions, no bulk dryout occurred. These results were consistent with the results from earlier small-scale experiments.
\end{abstract}


This page intentionally left blank. 


\section{TABLE OF CONTENTS}

1.0 BACKGROUND $\ldots \ldots \ldots \ldots \ldots \ldots \ldots \ldots \ldots \ldots \ldots \ldots$

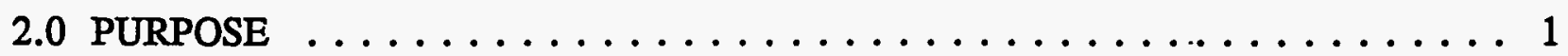

3.0 DESCRIPTION OF EQUIPMENT $\ldots \ldots \ldots \ldots \ldots \ldots \ldots \ldots \ldots$

4.0 CALIBRATION RUN $\ldots \ldots \ldots \ldots \ldots \ldots \ldots \ldots \ldots \ldots \ldots \ldots \ldots \ldots \ldots$

5.0 BOILING RUN $\ldots \ldots \ldots \ldots \ldots \ldots \ldots \ldots \ldots \ldots \ldots \ldots$

6.0 WATER MIGRATION RUN $\ldots \ldots \ldots \ldots \ldots \ldots \ldots \ldots \ldots \ldots \ldots \ldots$

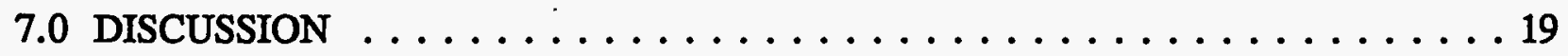

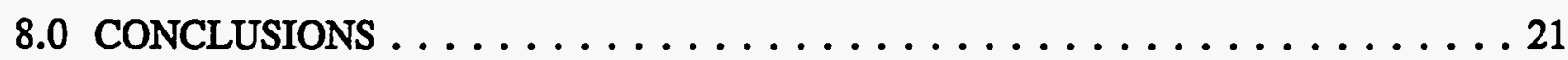

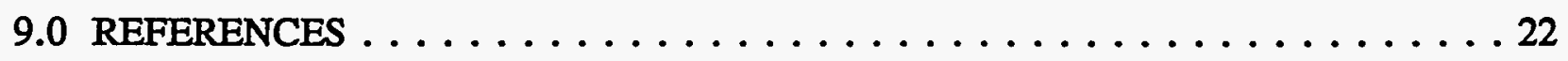

\section{APPENDIX}

A EXTRAPOLATION OF RESULTS OF FAI TESTS OF HEATED SLUDGE

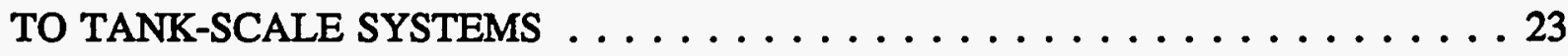




\section{LIST OF FIGURES}

1 Mud Test Geometry $\ldots \ldots \ldots \ldots \ldots \ldots \ldots \ldots \ldots \ldots \ldots$

2 Cage, Heaters and Thermocouples Prior to Placement of Simulant ......... 4

3 MMT-1 Centerline Temperatures (1) . . . . . . . . . . . . 6

4 MMT-1 Radial Temperatures $(1) \ldots \ldots \ldots \ldots \ldots \ldots \ldots \ldots$

5 Final Steady State Result $\ldots \ldots \ldots \ldots \ldots \ldots \ldots$

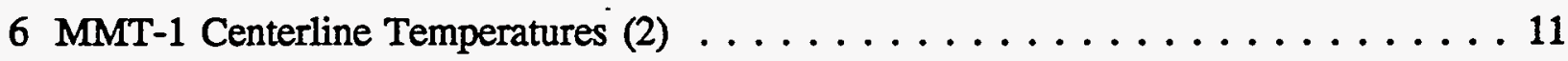

7 MMT-1 Radial Temperatures (2) $\ldots \ldots \ldots \ldots \ldots \ldots \ldots \ldots \ldots \ldots \ldots \ldots$

8 Thermal Contours . . . . . . . . . . . . . . . . 13

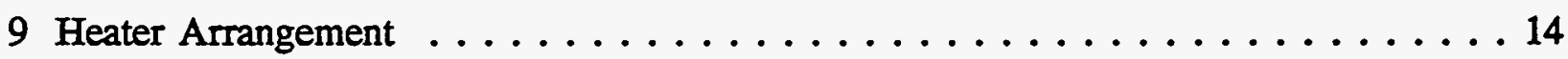

10 Best Fit Linear Regression Line $\ldots \ldots \ldots \ldots \ldots \ldots \ldots \ldots \ldots \ldots \ldots \ldots \ldots$

11 MMT-2 Centerline Temperatures $\ldots \ldots \ldots \ldots \ldots \ldots \ldots \ldots \ldots \ldots$

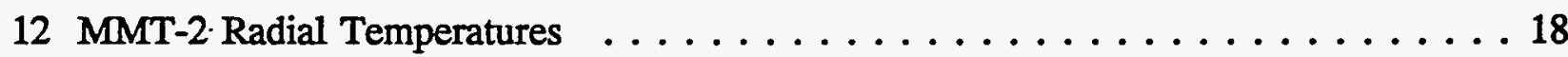

\section{LIST OF TABLES}

1 Sample Results: Weight Percent Water . . . . . . . . . . . . . . 15

2 Comparison with Actual Ferrocyanide Tanks . . . . . . . . . . . . . 19

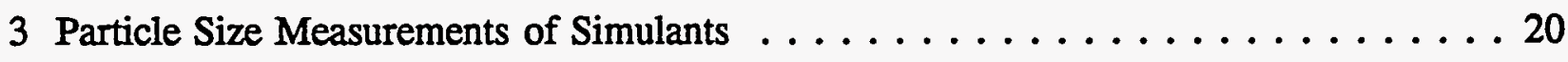




\section{MOISTURE MIGRATION TEST}

\subsection{BACKGROUND}

During the initial phases of the Ferrocyanide Safety Program, it was presumed that actual sludge in tanks would behave as if it were a two-phase system in which a brine phase would seep through the insoluble solid phase of ferrocyanide and other precipitated salts. After flowsheet materials were produced and extensively tested (Jeppson and Wong 1993), it became apparent that the ferrocyanide precipitates held extensive quantities of water (50\% by weight or more) that were far above what would be expected from hydrated salts. Because little or no draining. of this fluid occurred over a period of months, it was concluded that the precipitates and their solution would act as a homogenous single phase in much the same way as natural clays. Suggestions were made that the testing of clays could add to existing knowledge of sludge hydraulic and rheologic properties, at a much-reduced cost in chemicals and time over that required for flowsheet materials.

\subsection{PURPOSE}

Recent tests at Fauske \& Associates, Inc. (FAI) with both flowsheet ferrocyanide material and clays have explored certain aspects of heat flow and related hydraulic behavior. Because the test volumes were small in size $\left(10 \mathrm{~cm}^{3}\left[0.61 \mathrm{in}^{3}\right]\right.$ to 3 liters [0.80 gal]), questions have been raised concerning scaling the results to the typical tank size of $23 \mathrm{~m}$ (75 ft) in diameter and 0.61 to $3 \mathrm{~m} \mathrm{(2} \mathrm{to} 10 \mathrm{ft}$ ) of waste depth. The purpose of this report is to document a series of tests conducted to extend the initial FAI tests to a more typically sized scale in order to give confidence that the results would form a firm basis for estimating moisture migration scenarios in actual ferrocyanide sludge.

\subsection{DESCRIPTION OF EQUIPMENT}

Heaters for these tests consisted of sheathed resistance units $0.31 \mathrm{~cm}$ (1/8 in.) in diameter with a heated length of $244 \mathrm{~cm}$ (96 in.) for a total heated area of $243 \mathrm{~cm}^{2}$ (37.7 sq in.). Each heater was coiled in a horizontal plane with about $3.2 \mathrm{~cm}(1.25$ in.) between successive coils to a total diameter of $30 \mathrm{~cm}$ (12 in.). The non-heated end of the coil was bent at a right angle so that the electrical connections would be above the simulant material. Four 
heaters were used, with 13-cm (5-in.) spacing between each one. The bottom heater was $6.3 \mathrm{~cm}(2.5 \mathrm{in}$.$) above the test tank bottom, and the top heater then 15 \mathrm{~cm}(6 \mathrm{in}$.$) below the$ simulant surface.

Standard Type K sheathed 0.16-cm (1/16-in.)-diameter thermocouples were used. Calibration with ice water and boiling water showed them to be no more than 1 degree in error at 0 and $100{ }^{\circ} \mathrm{C}$ as read on the data recorder. Three thermocouples were placed along the vertical centerline of the heater array and three others were placed at the mid-plane of the test tank at various radii. Figure 1 illustrates the arrangement and gives critical dimensions of the heaters and thermocouples.

A cage was made of $0.95-\mathrm{cm}(3 / 8$-in.) stock sheet acrylic plastic to retain the heaters and thermocouples in their selected geometry while the simulant was being placed around them. The cage also facilitated mechanical anchoring of the hardware, and because it was open in design and had no part more than $1.27 \mathrm{~cm}(1 / 2 \mathrm{in}$.) wide, it minimized any thermal variations in the simulant. Figure 2 is a photograph of the cage, heaters, and thermocouples as assembled, just before placement of the clay simulant mixture.

After the heater cage was placed in the center of a galvanized steel, 0.91-m (3-ft)-diameter by $0.61-\mathrm{m}(2-\mathrm{ft})$-deep stock watering tank, the tank was filled with simulant. A plastic cover was placed over the entire assembly and taped to the sides of the tank so that evaporation water could not escape.

The simulant was made of tap water and commercial kaolin clay. Kaolin was chosen because it was used in prior FAI work, its physical properties are similar to actual waste, and its use avoided a number of safety and toxicology issues that may have resulted from other materials.

A number of small samples were made from the simulant, ranging from $35 \%$ to $65 \%$ water by weight. Portions of the samples were used to generate a density-vs.-water-content relationship. The samples were then examined by a number of laboratory personnel who had handled real tank waste samples or flowsheet simulants. While some samples of real waste had either more or less fluid than the present clay simulants, the lab personnel concluded that the $45 \%$ water sample most closely represented ferrocyanide waste sludge in terms of physical consistency. Therefore, the test was conducted with simulant material that was $45 \%$ water and $55 \%$ kaolin clay by weight. Because the material is approximately the consistency of peanut butter, a concrete vibrator unit was required to help flow the mixture into the test tank.

The reality of the experiment was less than the ideal described above. Although the test tank was initially sound, the extra weight and support configuration caused at least one hairline crack in the tank, which was observed during the initial heating. Water (not slurry) leaked from that point at such a rate that it evaporated into the room air before accumulating, so no estimate could be made of that loss. The test tank was slightly overfilled, so some water ran down the outside and was collected; most of this loss was in the first few days. After 18 


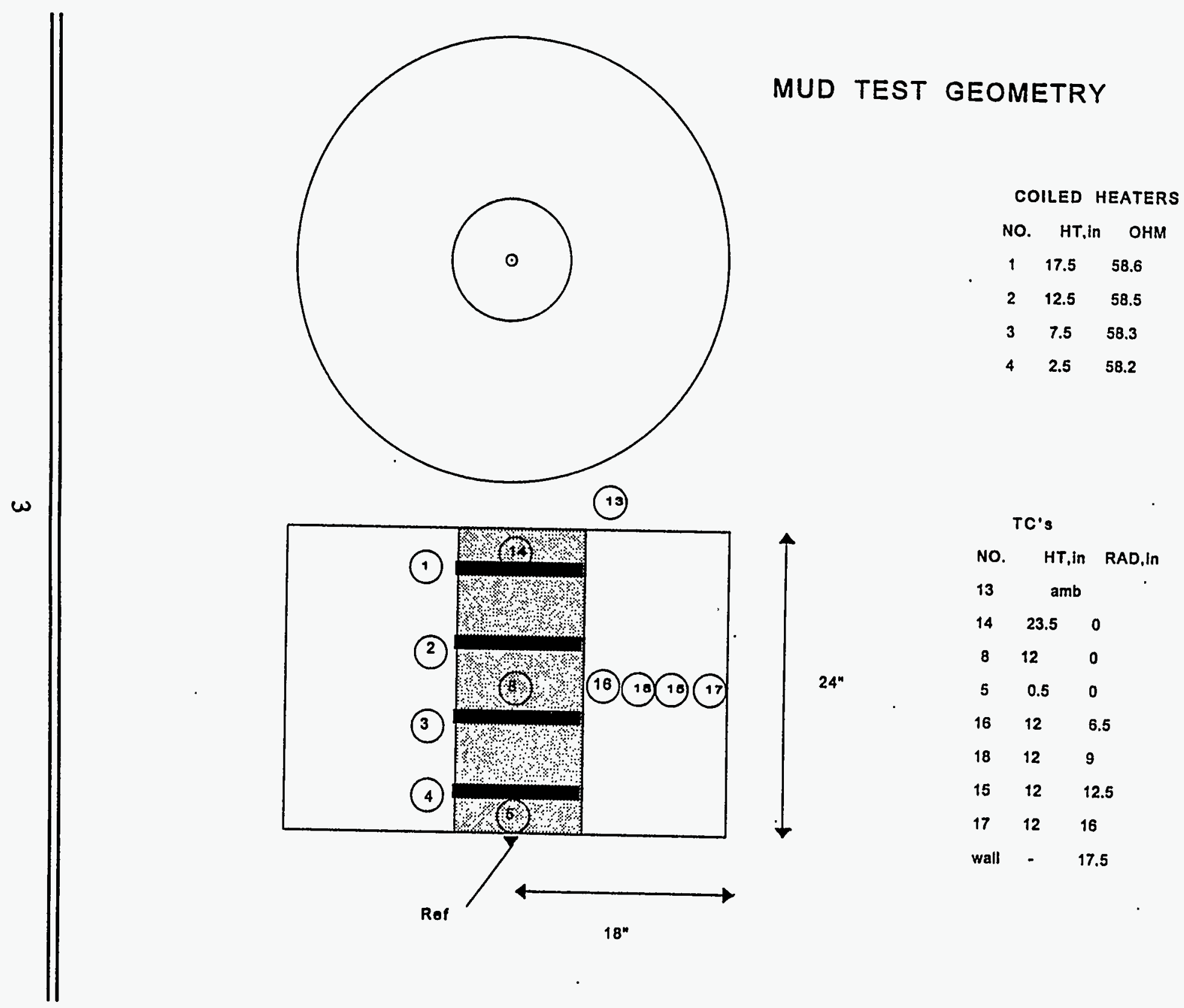


Figure 2. Cage, Heaters and Thermocouples

Prior to Placement of Simulant.

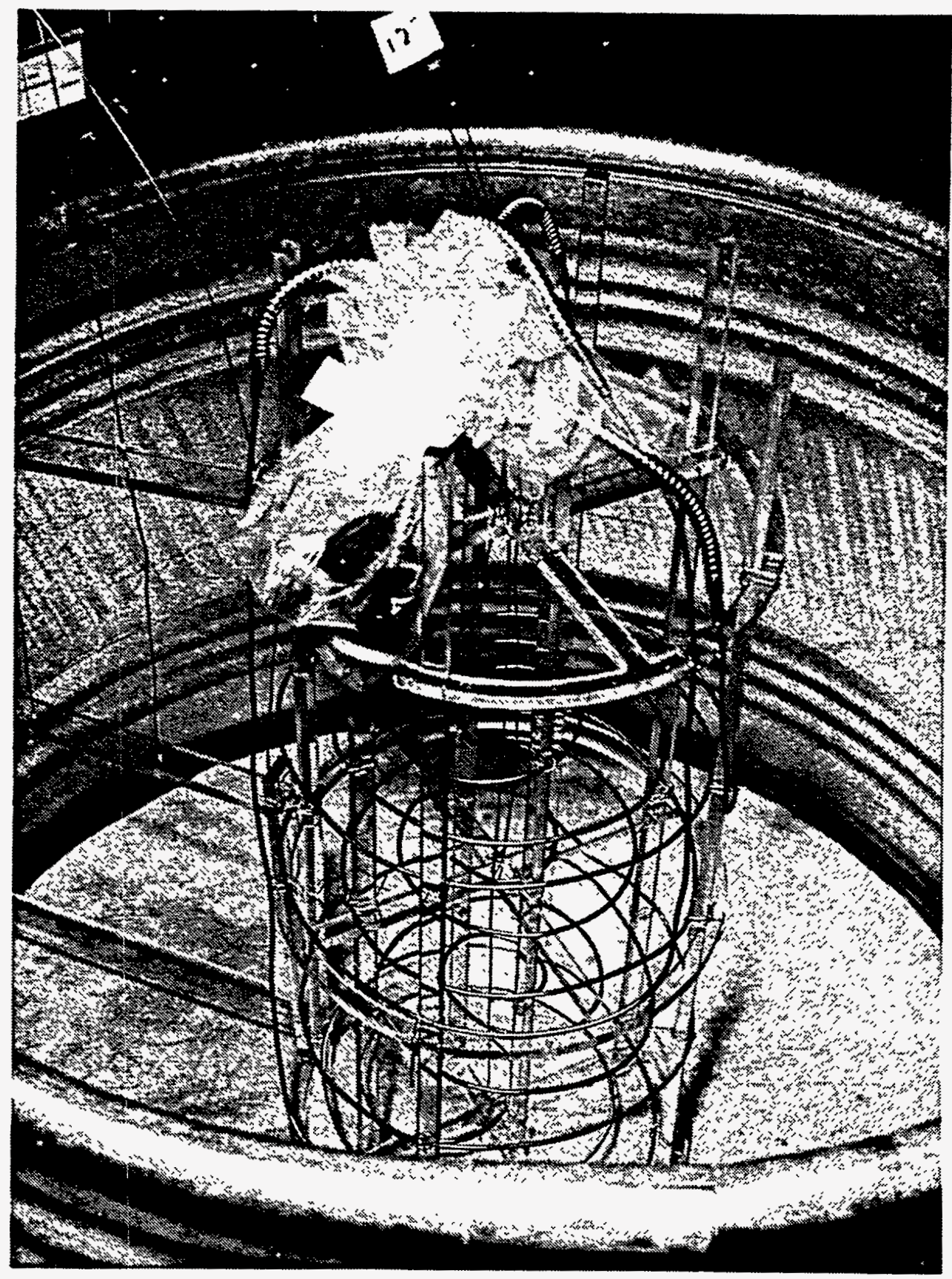


days, about $8.62 \mathrm{~kg}$ (19 lb) (of an original $316 \mathrm{~kg}$ [697 lb]) of water, not slurry, was collected, which would have changed the overall concentration from $45.06 \%$ to $44.37 \%$ water. Openings were made in the plastic cover for the cage, heater, and thermocouple leads, so some slight evaporative loss occurred. Further observations and data regarding the experiment are recorded in Greenhalgh (1992).

In the spring, the building heaters were set to maintain a $21^{\circ} \mathrm{C}\left(70^{\circ} \mathrm{F}\right)$ minimum temperature, but afternoon temperatures inside the building sometimes exceeded $26.6^{\circ} \mathrm{C}$ $\left(80^{\circ} \mathrm{F}\right)$ because the building has no air conditioning. These daily swings (typically $9{ }^{\circ} \mathrm{C}$ [15 $\left.{ }^{\circ} \mathrm{F}\right]$ or less) are obvious in the hourly ambient readings and also reflect back into the simulant material for several inches. Because the time constant for the mass is on the order of 24 hours and the experiments were typically run for several hundred hours, the temperature variations caused little impact.

After the test tank was filled, the cage was about $2.5 \mathrm{~cm}$ (1 in.) off center. However, the relative placement of the thermocouples and the heaters was unchanged, and the radial thermocouples were still on a 45.7-cm (18-in.) radius, so the effect of the off-center cage was ignored.

\subsection{CALIBRATION RUN}

A finite element computer model was constructed using a cylindrical relaxation grid of $1.27-\mathrm{cm}(1 / 2-$ in.) cells in both vertical and radial directions, and a time step increment of $0.01 \mathrm{hr}$. This program was operated to show the temperature history of the test tank at any of several locations. All pertinent constants, such as heat capacity, thermal conductivity, density, and heat transfer coefficients, could be altered to affect the outcome.

The first experiment was conducted by starting the four heaters at about 30 to 33 watts each, for a total of 127 watts for the array. This energy input was maintained at a constant value by the use of variable transformers for 21 days. Figures 3 and 4 show the results for the first week. The surface heat flux from the heaters was about 0.131 watts $/ \mathrm{cm}^{2}$ and the power density for the $0.30-\mathrm{m} \times 0.61-\mathrm{m}(1-\mathrm{ft} \times 2$-ft) cylinder was 2.85 watts/liter. These values are both noticeably lower than those used in the previous FAI experiments, but are higher than the actual waste tank averages by a factor of 300 to 3,000 .

The computer model used a density based on actual laboratory work previously described, and the heat capacity was calculated based on the weighted average of handbook values for clay and water. Numerous computational runs were then made, with the thermal conductivity and heat transfer coefficients varied, to achieve the best match to the tank heating experiment. 


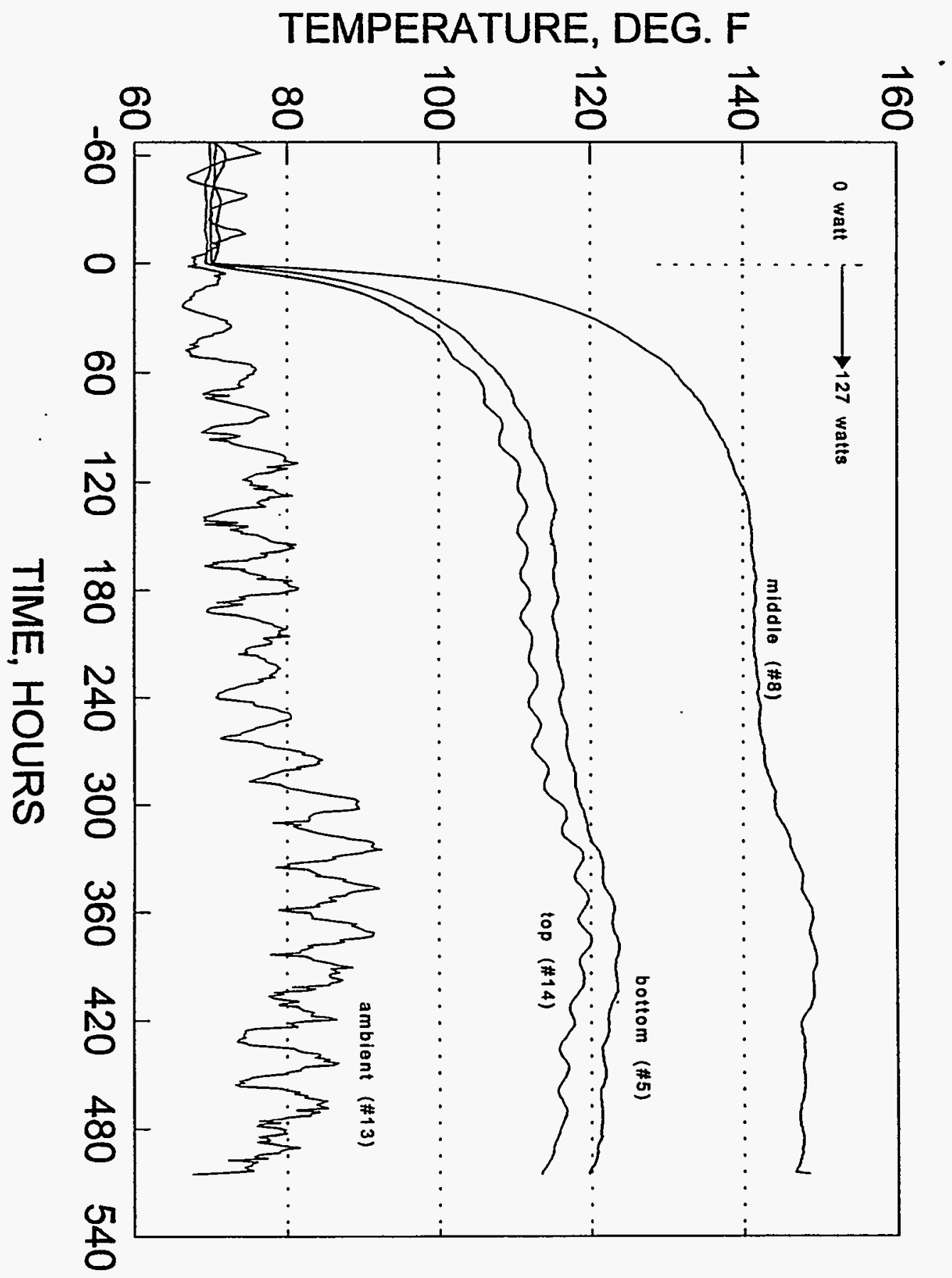

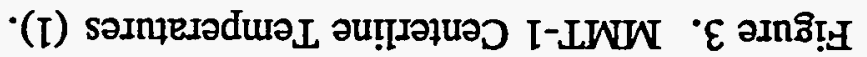




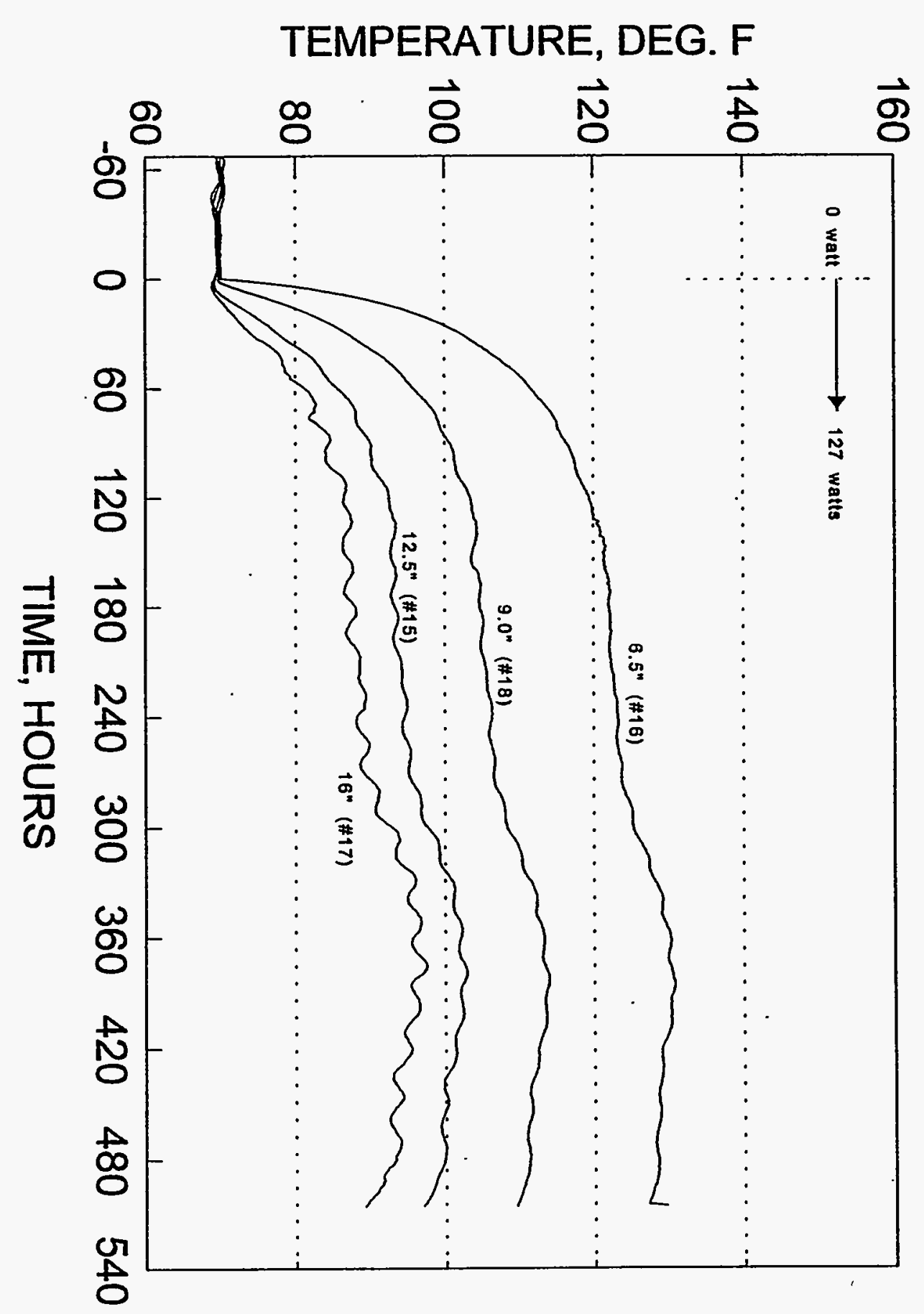

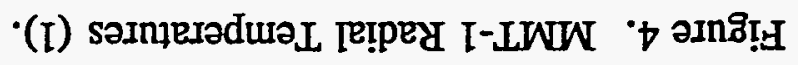


Figure 5 shows the final steady state result. The thermal contour lines are calculated based on the parameters that gave the best fit to the actual data. The points on the figure are the actual measurements from the test tank heating experiments. The parameter values were:

$$
\begin{aligned}
& \text { density }=2.15 \mathrm{~g} / \mathrm{cm}^{3} \quad \text { based on laboratory measurements. } \\
& \mathrm{C}_{\mathrm{p}}=0.573 \mathrm{Btu} / \mathrm{lb}-{ }^{\circ} \mathrm{F} \quad \text { based on handbook values. } \\
& =0.573 \mathrm{Cal} / \mathrm{g}-{ }^{\circ} \mathrm{C} \\
& \mathrm{k}=0.69 \mathrm{Btu} / \mathrm{hr}-\mathrm{ft}-^{\circ} \mathrm{F} \\
& =1.2 \mathrm{~W} / \mathrm{m}-{ }^{\circ} \mathrm{C} \\
& \text { based on best fit to actual run. NOTE: values ranging } \\
& h_{\text {top }}=\text { nat conv } \quad \text { based on best fit of } .5 *\left(0.19 \Delta T^{1 / 3}\right) \\
& h_{\text {xide }}=\text { nat conv } \quad \text { based on best fit of } 2.0 *\left(0.19 \Delta T^{1 / 3}\right) \\
& h_{\text {botrom }}=\text { nat conv } \quad \text { based on best fit of } 2.0 *\left(0.19 \Delta \mathrm{T}^{1 / 3}\right)
\end{aligned}
$$
from $0.53-0.65 \mathrm{Btu} / \mathrm{hr}-\mathrm{ft}-{ }^{\circ} \mathrm{F}$ for four ferrocyanide tanks have been estimated based on detailed calculations using measured tank temperatures; a fifth tank was 0.95

$\left(0.19 \Delta \mathrm{T}^{1 / 3}\right)$ is $\mathrm{Btu} / \mathrm{hr}-\mathrm{ft}^{2}{ }^{\circ} \mathrm{F}$ based on a temperature difference in ${ }^{\circ} \mathrm{F}$.

A check was also made of the simulant's actual water content. At the mid-plane of the array near the heaters, water content was $44.0 \%$ at about $54^{\circ} \mathrm{C}\left(130^{\circ} \mathrm{F}\right)$, and near the outer wall, water content was $43.7 \%$ at about $35^{\circ} \mathrm{C}\left(95^{\circ} \mathrm{F}\right)$. Water content of a portion of the original test simulant material kept in a storage can was $44.4 \%$ at $74{ }^{\circ} \mathrm{F}$. It appears that there was some water loss during mixing, but no significant variation within the heated volume.

\subsection{BOILING RUN}

After steady state conditions were reached in the calibration experiment, the power level was raised to 380 watts to determine the system's behavior when boiling was occurring in the heated volume.

Within a day, it was obvious that boiling was taking place. Faint but distinct bumping noises could be heard, similar to those from a full boiling pan of water on a stove. The central thermocouple rapidly rose to about $100^{\circ} \mathrm{C}\left(213^{\circ} \mathrm{F}\right)$ and remained at that value. Within a few days, vent holes could be seen in the simulant. The pulsing movement and high relative 
Figure 5. Final Steady State Result.

(Thermal Contour Lines at 127 Watts Input)

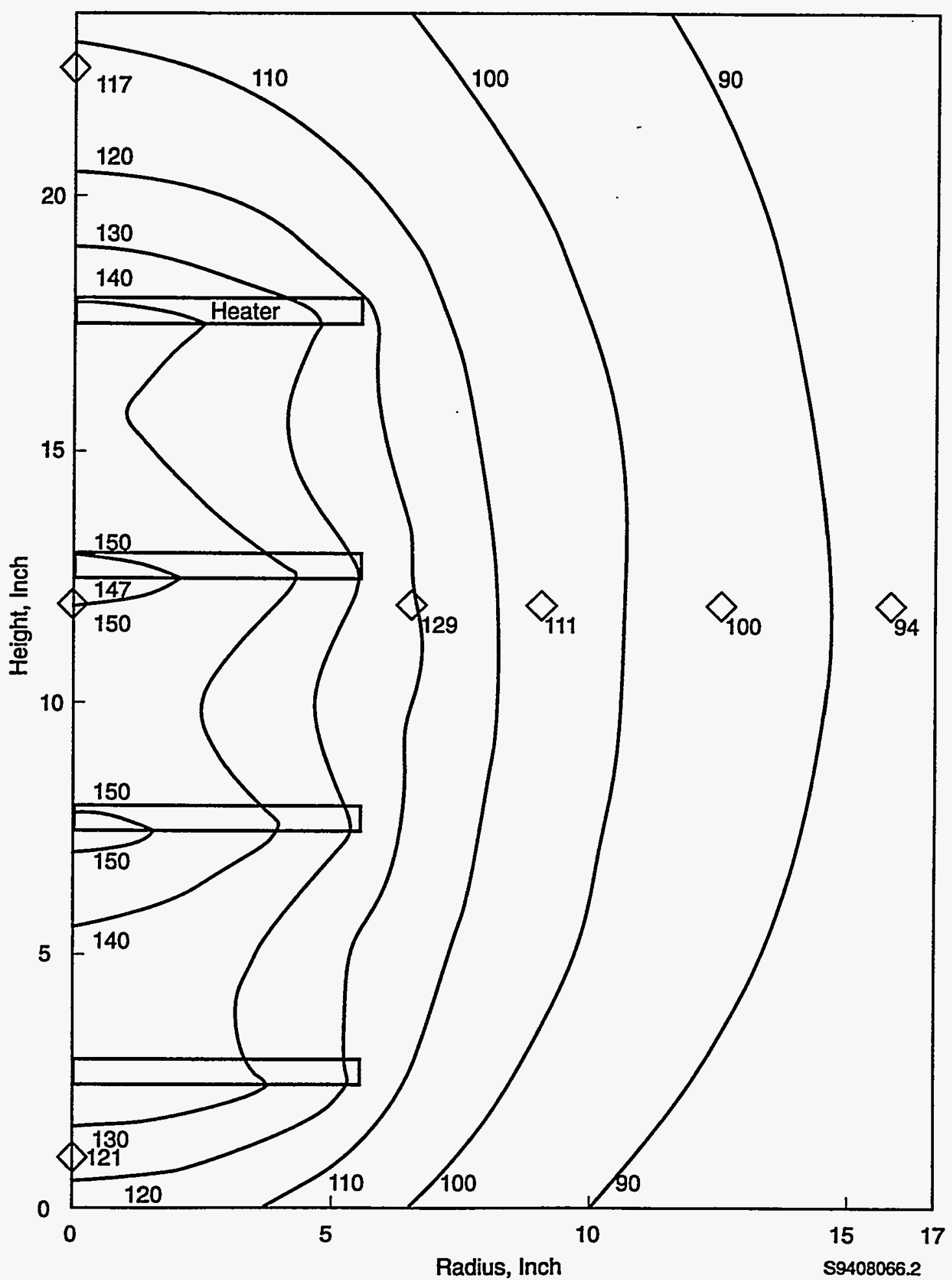


temperature of the plastic over these holes indicated that considerable amounts of steam were moving. As the temperature history showed (see Figures 6 and 7), the central temperatures abruptly changed by up to $6.6^{\circ} \mathrm{C}\left(20^{\circ} \mathrm{F}\right)$ several times, and not necessarily together. This implies that the vent paths occasionally changed on an irregular basis. Additional work was done with the computer model. The previous parameter values were used with one exception: if the temperature of a node was greater than $100^{\circ} \mathrm{C}\left(212^{\circ} \mathrm{F}\right)$, then a larger value for conductivity was assumed. Figure 8 shows the thermal contours for this situation, with diamonds indicating actual readings for the heated simulant. Interestingly, a factor of 2.0 increase in the conductivity was sufficient to give a good fit to the observed data. That is:

$$
\begin{aligned}
\mathrm{k}_{\text {normal }} & =0.69 \mathrm{Btu} / \mathrm{hr}-\mathrm{ft}-{ }^{\circ} \mathrm{F} \text { based on best fit to actual calibration run } \\
& =1.2 \mathrm{~W} / \mathrm{m}-{ }^{\circ} \mathrm{C} \\
\mathrm{k}_{\text {boiling }} & =1.38 \mathrm{Btu} / \mathrm{hr}-\mathrm{ft}-{ }^{\circ} \mathrm{F} \text { based on best fit to actual boiling run } \\
& =2.4 \mathrm{~W} / \mathrm{m}^{\circ} \mathrm{C}
\end{aligned}
$$

A check was also made of the simulant's actual water content. At the mid-plane of the array near the heaters, water content was $41.54 \%$ at about $101{ }^{\circ} \mathrm{C}\left(214^{\circ} \mathrm{F}\right)$, and near the outer wall, water content was $43.2 \%$ at about $45^{\circ} \mathrm{C}\left(114^{\circ} \mathrm{F}\right)$. It appears that very limited moisture variation occurs within the heated volume.

\subsection{WATER MIGRATION RUN}

While much effort has been expended analyzing boiling hot spots, a more subtle situation is that of a warm spot somewhat near the surface. If an accumulation of radionuclides were to occur at or near the surface, the temperature would increase. Then, water could evaporate over that area, condense on the tank ceiling or on the cooler portions of the surface, and hence be returned to some other area of the tank. The net result could be a drying out of some volume without ever reaching boiling.

To test this scenario, the simulant was slightly reconfigured. After a modest cooling period, the top several inches of simulant were removed, leaving $7.6 \mathrm{~cm}(3 \mathrm{in}$.) of material over the top of the uppermost, or \#1, heater. The other three heaters remained in place but were not operated. Thermocouples were moved so that one was at the center of the horizontal plane of the active heater and another was $2.5 \mathrm{~cm}$ ( 1 in.) above it. Figure 9 shows the arrangement for this test. Plastic sheeting was used to make a tent with low spots at the outer edge so that condensate would return to the edge and not the center, heated area.

The heater was operated at 63 watts for over 1,000 hours. On a weekly basis, samples of the clay were taken: 1) just under the simulant surface, over the heater; 2) just under the 
Figure 6. MMT-1 Centerline Temperatures (2).

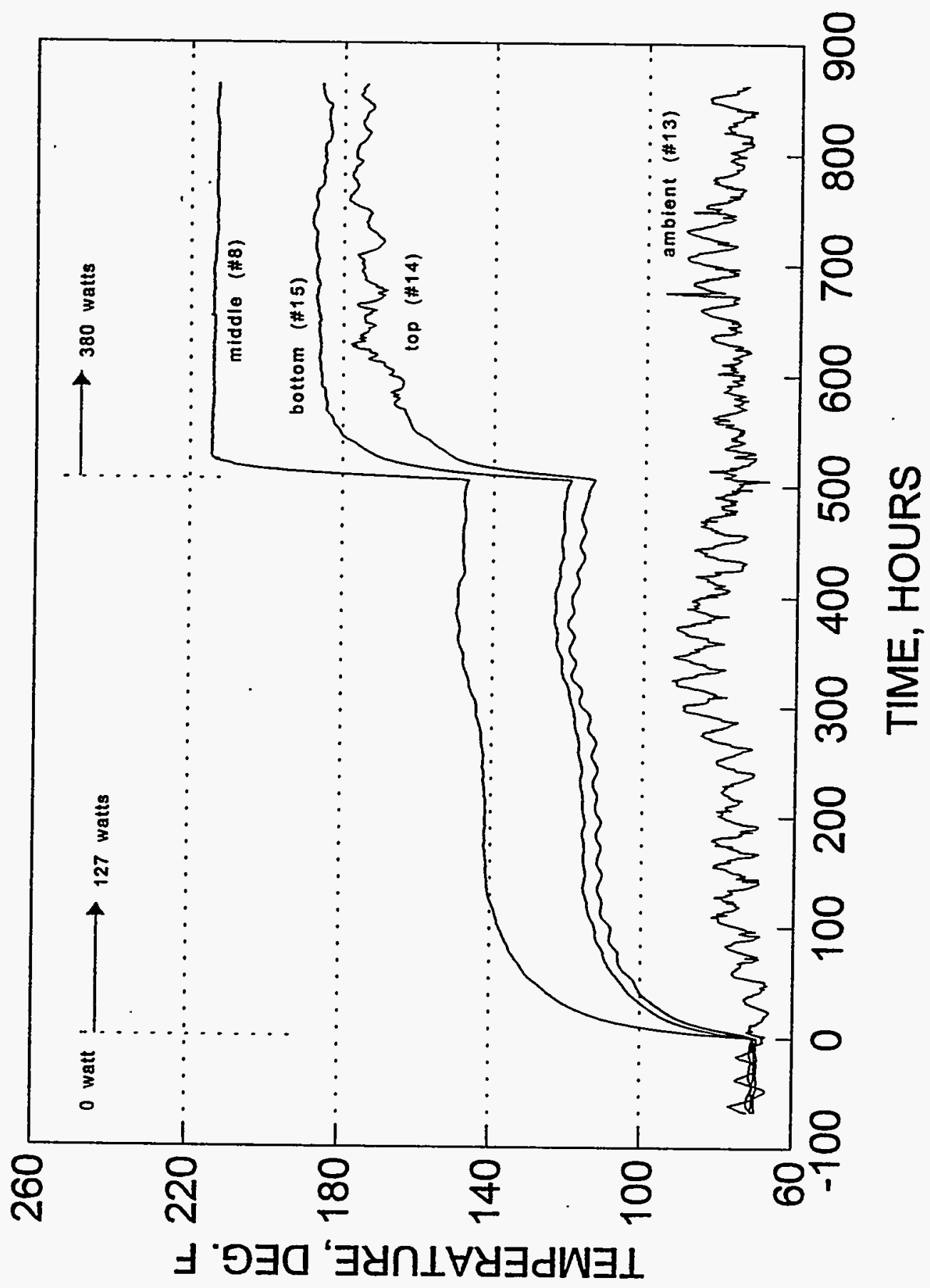


Figure 7. MMT-1 Radial Temperatures (2).

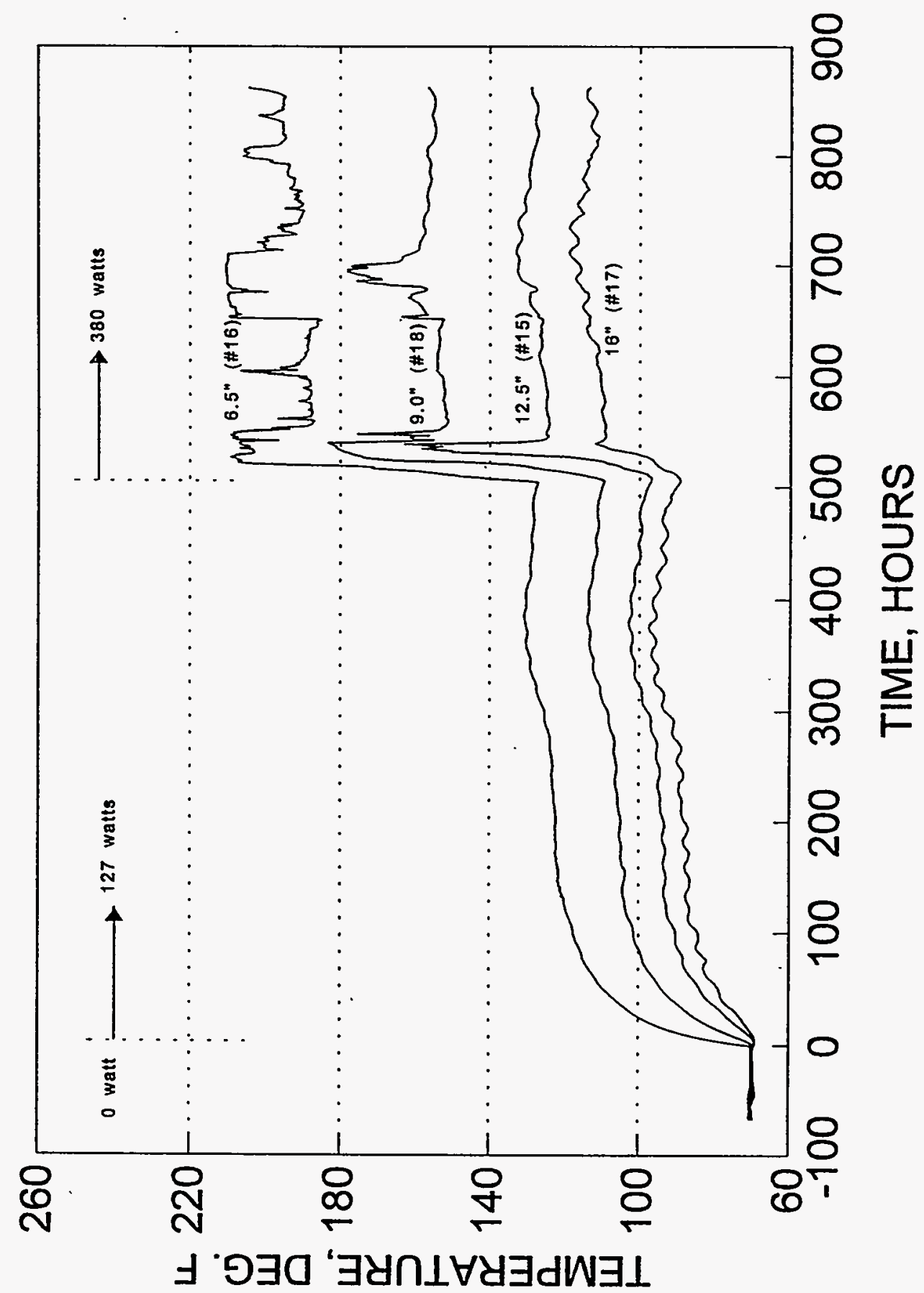


Figure 8. Thermal Contours.

(Thermal Contour Lines at 380 Watts Input)

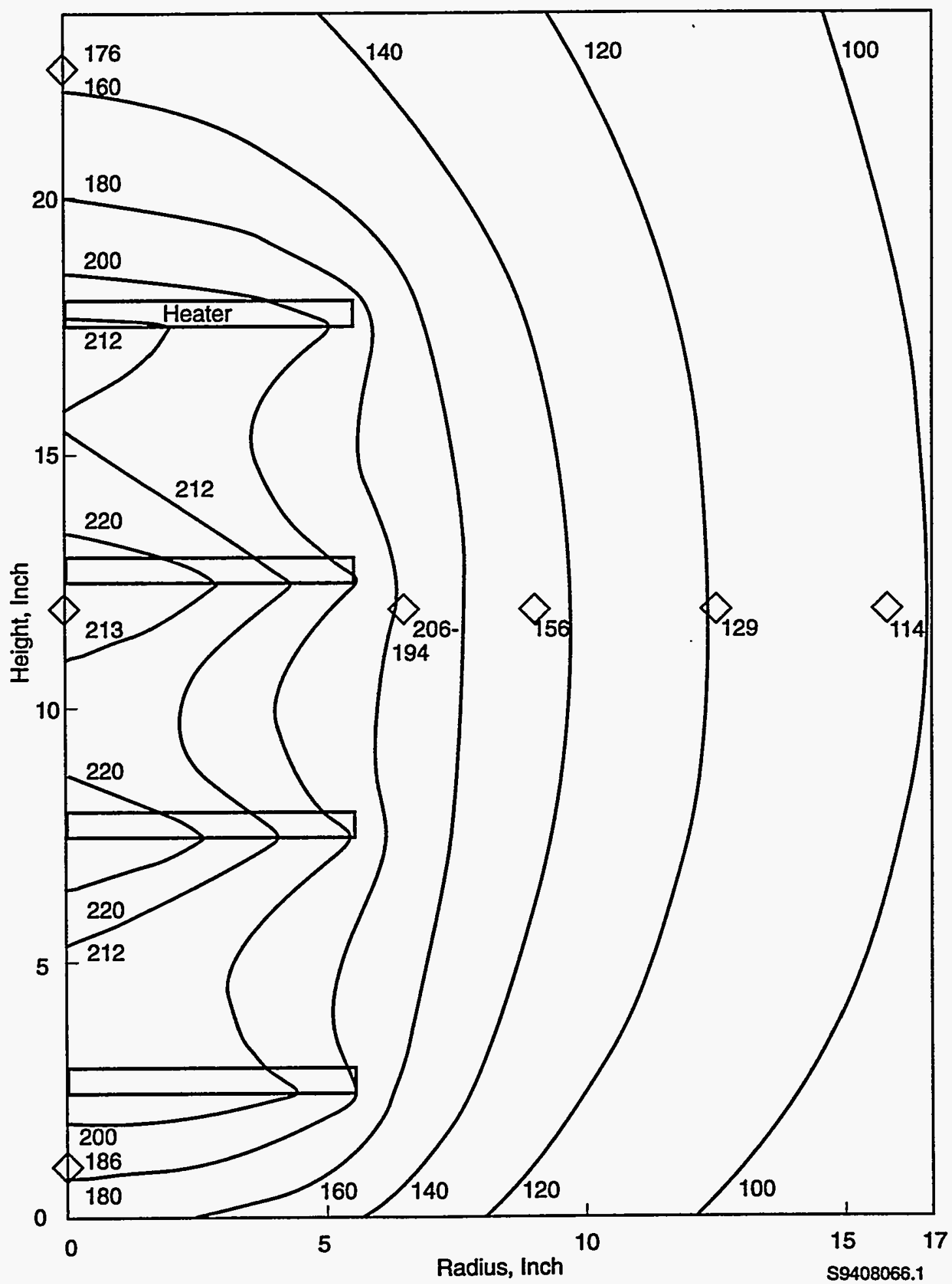




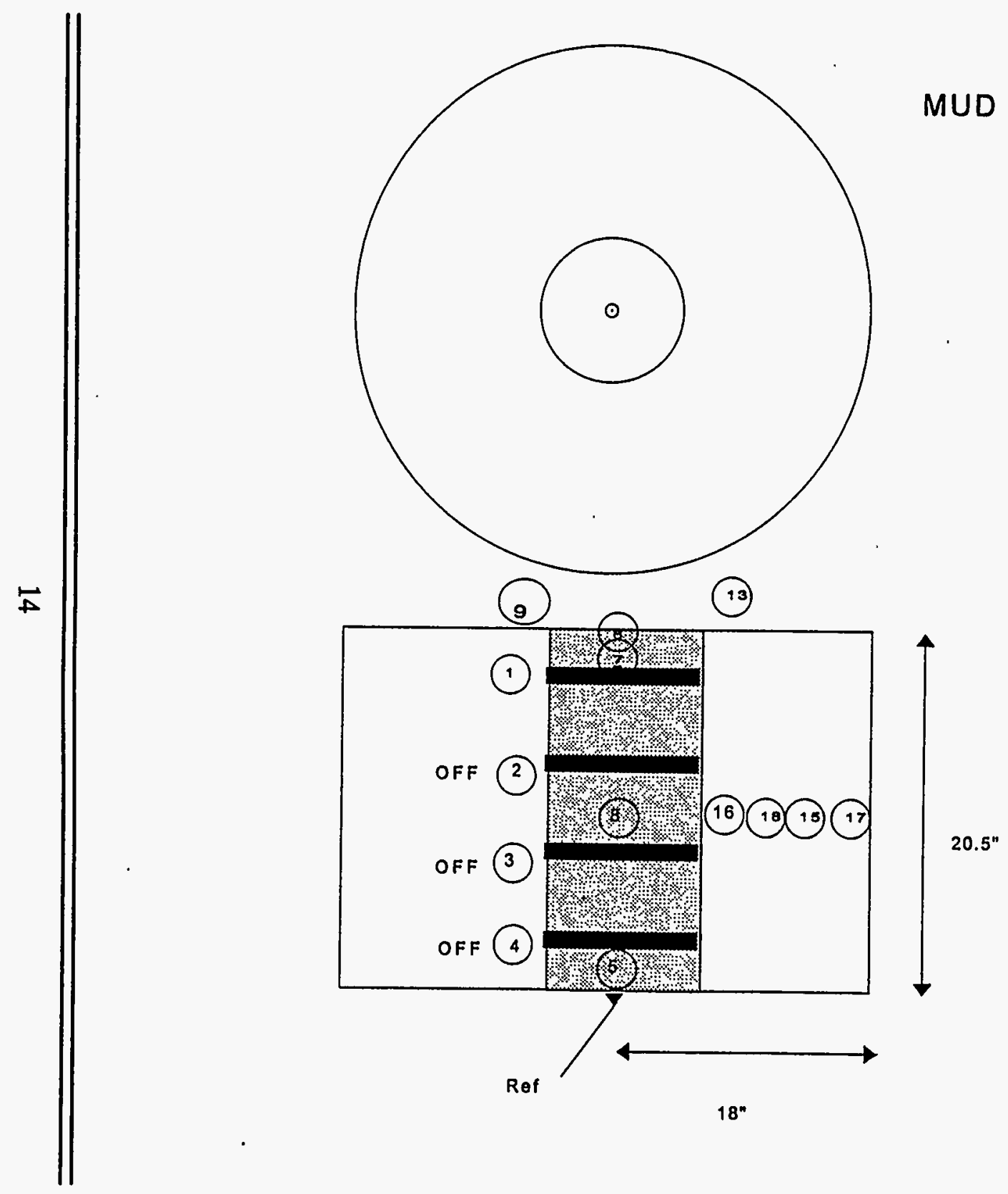

TEST GEOMETRY

\section{COILED HEATERS}

NO. HT OHM

$1 \quad 17.5 \quad 58.6$

$\begin{array}{lll}2 & 12.5 & 58.5\end{array}$

$\begin{array}{lll}3 & 7.5 & 58.3\end{array}$

$\begin{array}{lll}4 & 2.5 & 58.2\end{array}$

\begin{tabular}{clll}
\multicolumn{3}{c}{ TC's } \\
No. & HT,in & RAD,in \\
9 & vapor & \\
13 & amb & \\
6 & 18.5 & 0 \\
7 & 17.5 & 0 \\
8 & 12 & 0 \\
5 & 0.5 & 0 \\
16 & 12 & 6.5 \\
18 & 12 & 9 \\
15 & 12 & 12.5 \\
17 & 12 & 16 \\
wall & - & 17.5
\end{tabular}


simulant surface, near the edge of the tank; and 3) at the edge and near the bottom of the tank. Presumably, sample 3) was at the same temperature as the one above it, and differed

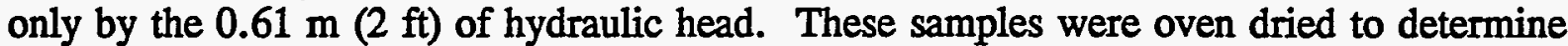
moisture content as a function of time and position. Table 1 gives the results as weight percent water:

Table 1. Sample Results: Weight Percent Water.

\begin{tabular}{|l|c|c|c|c|c|c|c|c|}
\hline \multirow{2}{*}{ Location } & \multicolumn{7}{|c|}{ Elapsed time, hours } \\
\cline { 2 - 9 } & zero & 164 & 404 & 500 & 739 & 837 & 1051 & 1197 \\
\hline $\begin{array}{l}\text { Center } \\
\text { surface }\end{array}$ & 40.9 & 39.4 & 39.2 & 38.0 & 38.5 & 39.2 & 40.1 & 39.0 \\
\hline Edge surface & 41.8 & 41.1 & 40.7 & 41.3 & 41.3 & 41.7 & 40.7 & 42.7 \\
& & & & & & & & 43.6 \\
\hline Edge bottom & - & 42.3 & 43.7 & 42.4 & 42.3 & 41.6 & 43.1 & 41.1 \\
\hline
\end{tabular}

Figure 10 shows the same data with the best fit linear regression line. The slope of all the lines is near zero and the confidence level is low $\left(r^{2}<0.3\right.$ where an $r^{2}=1$ implies a perfect fit and $r^{2}=0$ implies no correlation), so there is no shift in water inventory with time.

At 63 watts, all the water in a volume extending from $7.6 \mathrm{~cm}(3$ in.) directly above and $7.6 \mathrm{~cm}$ directly below the heater can be boiled off every 106 hours. This implies that the simulant's water inventory is potentially turning over rapidly while showing little or no net change in concentration.

Figures 11 and 12 show a portion of the temperature history of the test. Inspection showed that the heated volume of clay is well below boiling and that the ullage volume of captured air was warm enough to promote reasonable vapor transfer. Visual inspection of the surface showed drip marks in the clay at the outer perimeter but no significant puddling of water, despite some unevenness in the surface. There were a few cracks in the outer areas (but no obvious ones over the heater) $0.63 \mathrm{~cm}(1 / 4$ in.) deep by $0.16 \mathrm{~cm}$ wide totaling 51 to $76 \mathrm{~cm}$ (20 to 30 in.) in length.

Table 1 shows the moisture analysis over the course of the test. Within the accuracy of the determination (estimated at $\pm 0.5 \%$ ), it is difficult to see any trend. A linear regression analysis was performed on the data and showed the slope of the water content vs. time to be essentially zero with a low correlation coefficient $\left(\mathrm{r}^{2}<0.3\right)$. The differences between warm and cool surfaces never exceeds $2 \%$, which is similar to the top-to-bottom difference at the edge of the test tank. Whatever the water return mechanism is, it is certainly sufficient to match the power density over the heated volume, which is 600 to 6,000 times the average of a real waste tank. 
Figure 10. Best Fit Linear Regression Line.

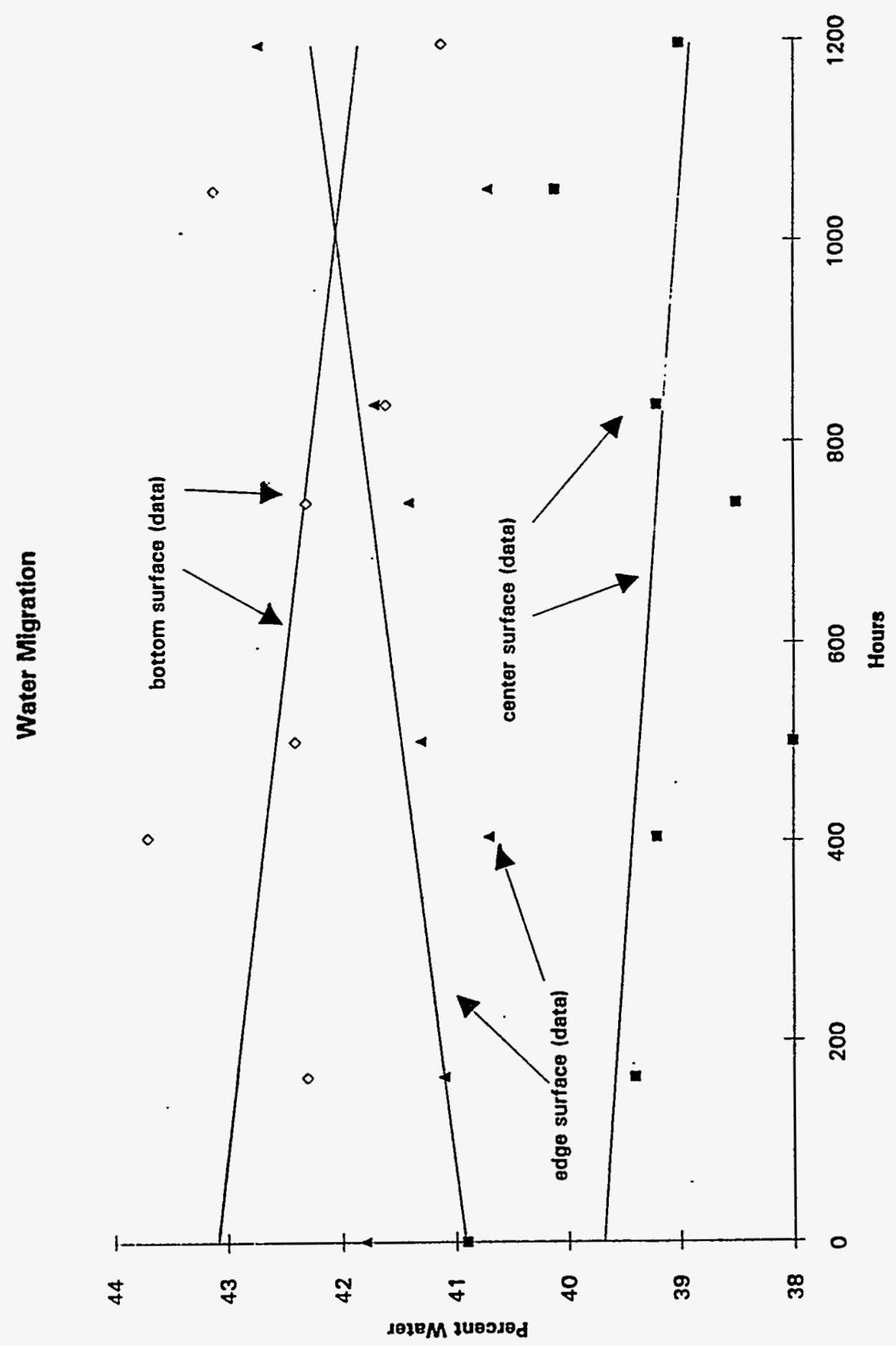


Figure 11. MMT-2 Centerline Temperatures.

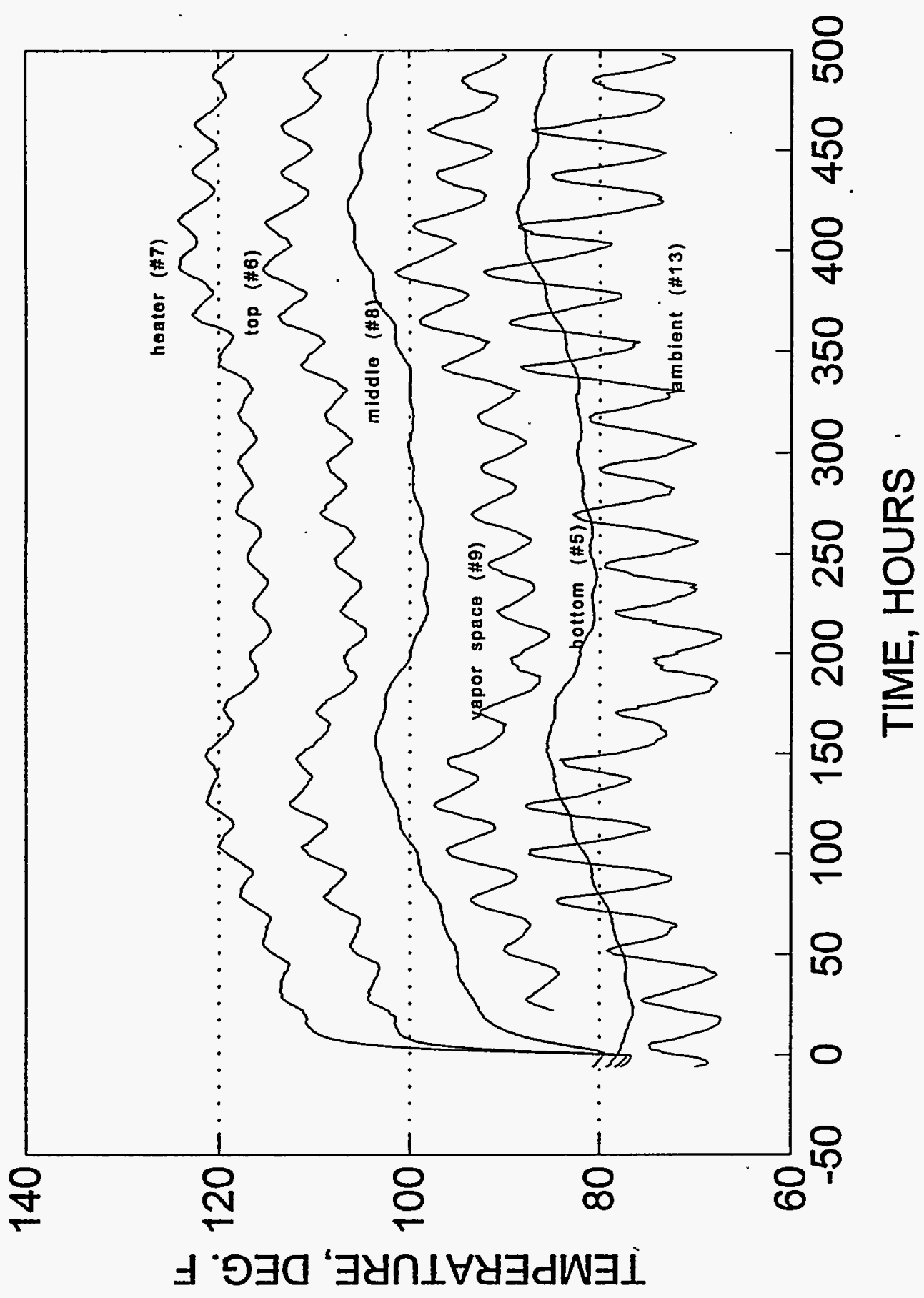


Figure 12. MMT-2 Radial Temperatures.

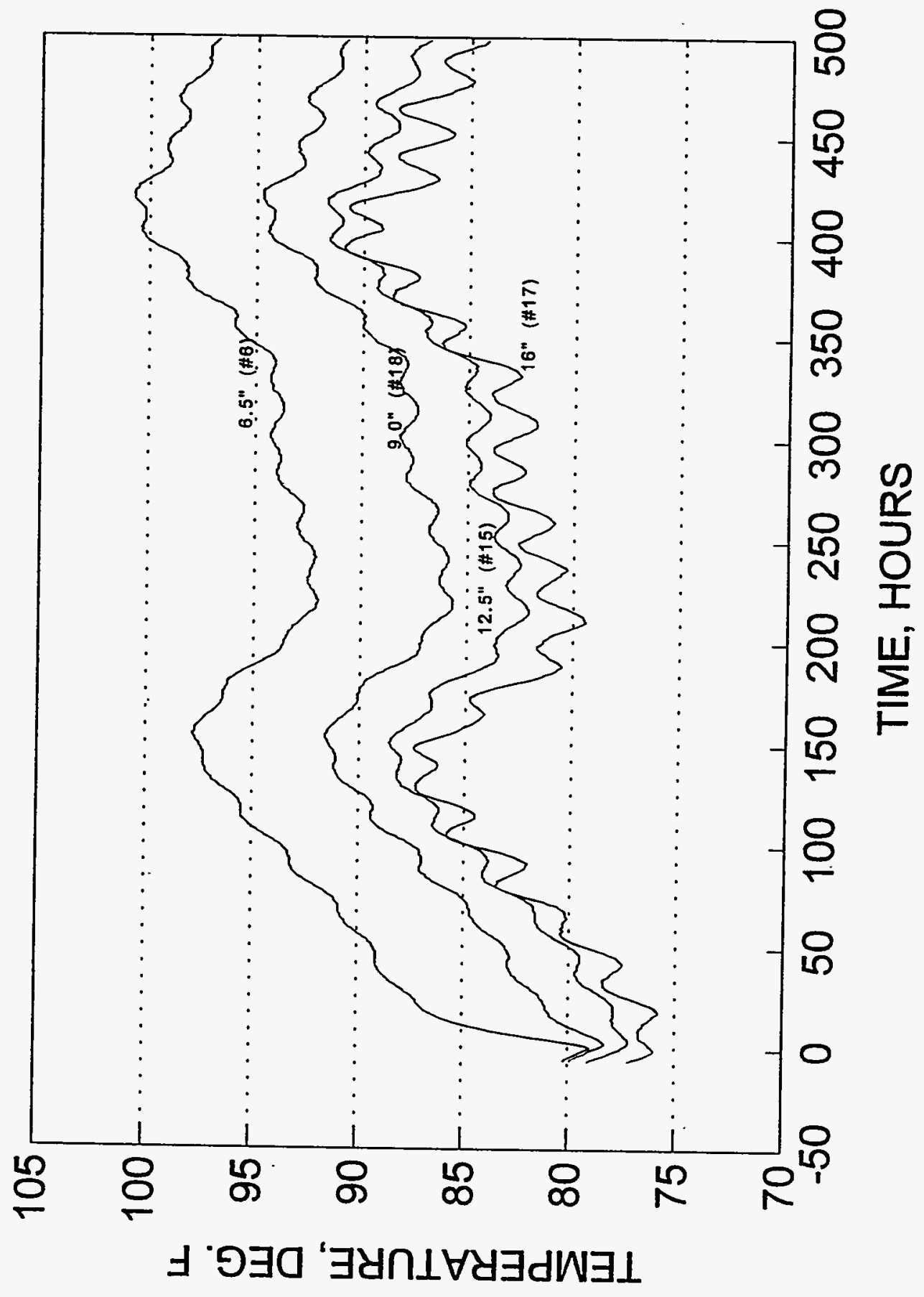




\subsection{DISCUSSION}

Table 2 compares the various experiments with pertinent values for the actual ferrocyanide tanks:

Table 2. Comparison with Actual Ferrocyanide Tanks.

\begin{tabular}{|l|c|c|c|c|}
\hline & $\begin{array}{c}\text { Total } \\
\text { Power }\end{array}$ & $\begin{array}{c}\text { Heater } \\
\text { Surface } \\
\text { Flux }\end{array}$ & $\begin{array}{c}\text { Heated } \\
\text { Volume } \\
\text { Density }\end{array}$ & QDD \\
\hline & watt & watt/cm2 & watt/liter & watt/m \\
\hline Calibration & 127 & 0.131 & 2.85 & 167 \\
\hline Boiling & 380 & 0.391 & 8.53 & 499 \\
\hline Migration & 63 & 0.259 & 5.67 & 83 \\
\hline Actual Tanks & $600-3000$ & - & $0.009-0.0009$ & $32-158$ \\
\hline
\end{tabular}

Relationships have been derived for scaling the heat and mass transfer phenomena (see Appendix A). Equivalent results are obtained when the product of surface heat flux and diameter $\left(\mathrm{Q}_{0}{ }^{*} \mathrm{D}\right)$ are the same. This implies that the results seen in the migration test are equivalent to those which would occur in actual tanks, and that dryout of an actual tank warm spot would not occur. Because dryout also did not occur in the test tank at 500 watts $/ \mathrm{m}$, one could reason that a real tank of less or equal value is also safe. For a real tank to exceed this value, all 3,000 watts of the hottest tank would have to be concentrated in less than $10 \%$ of the surface area. Because this is highly unlikely (i.e., it is contrary to what is predicted by the second law of thermodynamics), neither boiling nor migration provide a dryout mechanism. 
Additionally, a particle size analysis was done on the clay mixture, using the same equipment, personnel, and procedures as for previous flowsheet materials. The body of Table 3 is reproduced from Jeppson and Wong (1993) with the kaolin results added at the bottom:

Table 3. Particle Size Measurements of Simulants.

\begin{tabular}{|c|c|c|c|}
\hline \multirow[t]{2}{*}{ Simulant } & \multicolumn{3}{|c|}{ Median Diameter $(\mu \mathrm{m})$} \\
\hline & Number & Area & Volume \\
\hline $\begin{array}{c}\text { In-Farm-1 Top Fraction } \\
\text { Acquisition Range } \\
0.5-60 \\
0.5-150\end{array}$ & $\begin{array}{l}0.68 \\
0.76\end{array}$ & $\begin{array}{l}0.80 \\
0.81\end{array}$ & $\begin{array}{l}10.9 \\
21.3\end{array}$ \\
\hline $\begin{array}{c}\text { In-Farm-1 Bottom Fraction } \\
\text { Acquisition Range } \\
0.5-60 \\
0.5-150\end{array}$ & $\begin{array}{l}0.69 \\
0.77\end{array}$ & $\begin{array}{l}0.90 \\
0.91\end{array}$ & $\begin{array}{l}5.1 \\
7.8\end{array}$ \\
\hline $\begin{array}{c}\text { In-Farm-2 Top Fraction } \\
\text { Acquisition Range } \\
0.5-60 \\
0.5-150\end{array}$ & $\begin{array}{l}0.69 \\
0.76\end{array}$ & $\begin{array}{l}0.82 \\
0.84\end{array}$ & $\begin{array}{l}19.5 \\
14.3\end{array}$ \\
\hline $\begin{array}{c}\text { In-Farm-2 Bottom Fraction } \\
\text { Acquisition Range } \\
0.5-60 \\
0.5-150\end{array}$ & $\begin{array}{l}0.70 \\
0.76\end{array}$ & $\begin{array}{l}0.85 \\
0.83\end{array}$ & $\begin{array}{l}16.1 \\
16.8\end{array}$ \\
\hline $\begin{array}{c}\text { U-Plant-2 Top Fraction } \\
\text { Acquisition Range } \\
0.5-60 \\
0.5-150\end{array}$ & $\begin{array}{l}0.66 \\
0.82\end{array}$ & $\begin{array}{l}0.80 \\
1.58\end{array}$ & $\begin{array}{l}1.4 \\
4.4\end{array}$ \\
\hline $\begin{array}{l}\text { U-Plant-2 Bottom Fraction } \\
\text { Acquisition Range } \\
0.5-60 \\
0.5-150\end{array}$ & $\begin{array}{l}0.73 \\
0.77\end{array}$ & $\begin{array}{l}1.56 \\
0.95\end{array}$ & $\begin{array}{l}4.1 \\
3.9\end{array}$ \\
\hline $\begin{array}{c}\text { Kaolin in Water } \\
\text { Acquisition Range } \\
0.5-60 \\
0.5-150\end{array}$ & $\begin{array}{l}0.95 \\
1.37\end{array}$ & $\begin{array}{l}6.51 \\
6.02\end{array}$ & $\begin{array}{l}12.6 \\
15.4\end{array}$ \\
\hline $\begin{array}{c}\text { Kaolin in Alcohol } \\
\text { Acquisition Range } \\
0.5-60 \\
0.5-150\end{array}$ & $\begin{array}{l}0.93 \\
1.24\end{array}$ & $\begin{array}{l}2.85 \\
2.86\end{array}$ & $\begin{array}{l}3.8 \\
3.7\end{array}$ \\
\hline
\end{tabular}


One group of measurements was done using distilled water as the dispersing media, and the other group used ethanol. The flowsheet materials used the mother liquor, which is a saturated solution of strong electrolytes. It might be argued that the measurement of clay in ethanol is more realistic than in water, so both sets of data are provided. The particle sizes for the clay are similar to those for the flowsheet materials, which suggests that the hydraulic properties of clay and ferrocyanide sludges should be similar.

\subsection{CONCLUSIONS}

The first calibration run, with all temperatures below boiling, demonstrated that the claywater mixture behaved as if it were a homogenous, solid body with pure thermal conduction within the volume. The natural convection loss coefficients are within the expected range. Altogether, the system behaved as expected. A hairline crack was observed that permitted a small volume of liquid to escape the test tank, but the clay was retained.

The boiling run showed a continuation of expected behavior. Vent paths of steam were observed and their geometry varied with time. The boiling zone was small and a modest increase in effective thermal conductivity was sufficient to describe the behavior on a gross scale.

The water migration run showed that surface dryout does not result from a local surface region of elevated temperature. It appears that the water evaporated from the warm surface is easily replenished by mechanisms such as capillary flow. 


\subsection{REFERENCES}

Crowe, R. D., M. Kummerer, and A. K. Postma, 1993, Estimation of Heat Load in Waste Tanks Using Average Vapor Space Temperatures, WHC-EP-0709, Westinghouse Hanford Company, Richland, Washington.

Greenhalgh, W. O., 1992, Laboratory Notebook WHC-N-613, issued to W. O. Greenhalgh June 17, Westinghouse Hanford Company, Richland, Washington.

Jeppson, D. W. and J. J. Wong, 1993, Ferrocyanide Waste Simulant Characterization, WHC-EP-0631, Westinghouse Hanford Company, Richland, Washington. 


\section{APPENDIX A}

\section{EXTRAPOLATION OF RESULTS OF FAI TESTS OF HEATED SLUDGE TO TANK-SCALE SYSTEMS}


WHC-EP-0800

This page intentionally left blank. 


\section{APPLICATION OF HEATED SLUDGE TEST DATA TO TANK-SCALE SYSTEMS}

Although the Hanford heated sludge tests were at a considerably larger. scale than similar tests performed by Fauske and Associates, Inc., they are still at a much smaller scale, but much larger heat flux, than the ferrocyanide waste tanks. The discussion below relates the effects of scale and heat flux, and thereby provides a basis for applying the test data to the tank dimensions.

In the absence of cracking, which was not observed in the Hanford tests, the flow of water to replace that lost by evaporation will be by diffusion through the sludge. The mass flux may be expressed by the equation.

$$
\begin{aligned}
& J=D d C / d r \\
& \text { where } C=\text { moisture content } \\
& r=\text { radial distance } \\
& D=\text { diffusivity of water in sludge (function of } C \text { ) }
\end{aligned}
$$

Define the dimension-less parameters:

$$
\begin{aligned}
& \Psi=J \lambda / Q_{0} \\
& \beta=\left(C_{\infty}-C\right) / C_{\infty} \\
& \gamma=I / R
\end{aligned}
$$

where $C_{\infty}=$ moisture content well away from heated region (saturated)

$R=$ diameter of heater or hot spot

$Q_{0}=$ heat flux at surface of heater or at boundary of hot spot

$\lambda=$ heat of vaporization of water

The boundary condition is $C=C_{\infty}$ for large values of $r$, well away from the heated region and near the outer boundaries of the tank or test facility.

On substitution,

$$
\psi=-\frac{D C_{\infty} \lambda}{Q_{0} R} \cdot \frac{d \beta}{d \gamma}
$$

The boundary condition is

$$
B=0 \text { for large } y \text {. }
$$

If the parameters $D, C_{\infty}$, and $\lambda$ are approximately the same as in the tank waste, and if geometric similarity is be assumed, then the requirement for similar solutions in the two cases is that the product $Q_{0} R$ be the same. This may be used as the basis for scaling test results to the tanks. 
In this test with 63 watts distributed over a 1-foot diameter circle, the upward heat flux to the surface is $860 \mathrm{w} / \mathrm{m}^{2}$. The product $Q_{0} R$ is $132 \mathrm{w} / \mathrm{m}$. For a tank hot spot giving a $2-m$ diameter $(1-m$ radius) of surface with high heat flux, a heat flux of at least $132 \mathrm{w} / \mathrm{m}^{2}$ could be accommodated without dryout, assuming sludge properties similar to the Kaolin test. The tankaverage upward heat fiux in the highest-power tank $(B Y-106)$ is $3000 w / 410 \mathrm{~m}^{2}$ or $7.3 \mathrm{w} / \mathrm{m}^{2}$.

This heat flux is thus $132 / 7.3$ or 18 times the tank average. For other size hot spots:

Hot Spot Diameter, $m$

$$
\begin{gathered}
0.5 \\
1 \\
2 \\
4
\end{gathered}
$$

\section{Heat Flux as Multiple of Tank Average}

\section{3}

37

18

Hot spots capable of such surface heat fluxes over such an area are considered to be highly unlikely, and dryout by such a mechanism does not seem credible. However, two things must be kept in mind here.

$0 \quad$ The heat input in this test was selected to avoid boiling and to give sludge temperatures comparable to what might be present in the tanks. No attempt was made to determine the maximum heat flux which could be reached without dryout. There is nothing to suggest that much larger heat fluxes could not be accommodated without dryout. The analysis is therefore only a bound on a possible limit, and perhaps highly conservative.

- Application of Kaolin test data to the tank sludge is a problem distinct from the scaling problem discussed above. 


\section{DISTRIBUTION}

Number of copies

QFFSITE

6

U.S. Department of Energy

EM-36, Trevion II

12800 Middlebrook Road

Germantown, MD 20874

James V. Antizzo

Charles O'Dell (4)

John C. Tseng

1

Arlin K. Postma

3640 Ballard Road

Dallas, OR 97338

1

Fauske and Associates, Inc. 16 W070 W. 83rd St.

Burr Ridge, IL 60521

Hans K. Fauske

3

Science Applications International Corporation 20300 Century Blvd, Suite 200-B

Germantown, MD 20874

Ray S. Daniels (3)

State of Washington - Department of Ecology

1 Michael T. Gordon

P. O. Box 47600

Olympia, WA $98504-7600$

1

Alex Stone

$1315 \mathrm{~W}$ 4th Avenue

Kennewick, WA 99336 


\section{DISTRIBUTION (continued)}

\section{ONSITE}

12

U.S. Department of Energy. Richland Operations Office

R. F. Christensen (4)

R. E. Gerton (4)

A. G. Krasopoulos

A4-81

Public Reading Room

H2-53

RL Docket File (2)

Pacific Northwest Laboratory

G. F. Schiefelbein

C. S. Simmons

K6-77

Hanford Technical Library

P8-55

Westinghouse Hanford Company

H. Babad

S7-30

G. L. Borsheim

H5-27

R. J. Cash (2)

S7-15

M. D. Crippen

L5-31

D. R. Dickinson

L5-31

G. T. Dukelow

S7-15

J. M. Grigsby

H4-62

M. E. Huda

R3-08

M. N. Islam

R3-08

D. W. Jeppson

L5-31

M. Kummerer

H4-62

J. M. McLaren

$\mathrm{HO}-34$

J. E. Meacham

S7-15

Central Files

L8-04

Document Processing and Distribution (2)

L8-15

EDMC

H6-08

OSTI (2)

L8-07

TFIC

R1-20 